\title{
Does protein content influences accumulation and biomagnification of tantalum in fishes and invertebrates of marine coastal environments?
}

\author{
Rocío Ricciardi $^{1}$, Winfred Espejo ${ }^{2}$, Ricardo Barra ${ }^{3}$, Gustavo Chiang ${ }^{2}$ \& José E. Celis ${ }^{1}$ \\ ${ }^{1}$ Departamento de Ciencia Animal, Facultad de Ciencias Veterinarias \\ Universidad de Concepción, Chillán, Chile \\ ${ }^{2}$ Melimoyu Ecosystem Research Institute, Fundación MERI, Santiago, Chile \\ ${ }^{3}$ Department of Aquatic Systems, Facultad de Ciencias Ambientales and EULA-Chile Centre \\ Universidad de Concepción, Concepción, Chile \\ Corresponding author: José E. Celis (jcelis@udec.cl)
}

\begin{abstract}
Tantalum (Ta) is a rare transition metal widely used in the manufacture of new technologies such as computers, cell phones, solar panels and implants in biomedicine, and their use is continuously increasing. Most non-essential metals are immobilized in the organism through complexation with proteins, but it is not known if new-technology elements (such as Ta) present the same behavior. In aquatic environments, metals tend to concentrate in biota and some can be biomagnified through the trophic chain, even reaching humans. This study aimed to investigate any possible relationship between $\mathrm{Ta}$ and proteins. Invertebrates and fishes were collected from coastal marine ecosystems of northern Chile, Patagonia, and South Shetland Islands (Antarctic Peninsula). A direct positive relationship was found between Ta and total proteins throughout the food chain from marine ecosystems of the Patagonia and the Antarctic Peninsula area, revealing that proteins are probably the pathway by which Ta bioaccumulates and biomagnifies in macroinvertebrates and fish of pristine coastal marine environments. Our data suggest that site-specific factors (e.g., water temperature, $\mathrm{pH}$, geography) may be influencing the environmental fate of Ta. Therefore, further studies are needed to understand the biological implications of this metal.
\end{abstract}

Keywords: proteins; tantalum; bioaccumulation; northern Chile; Patagonia; Antarctica

Marine environments are often very vulnerable and exposed to xenobiotics because of their proximity to human activities through industrial emissions, urban runoff, municipal discharges and biocides used in agriculture (Muñoz \& Becker, 1999; Bargagli, 2008). Metals can be bioaccumulated in aquatic organisms and magnified throughout the food chain, affecting human health (Zhou et al., 2008). Bioaccumulation is a type of metal absorption through which it can be incorporated in biota and immobilized through complexation with intracellular proteins (Harms et al., 2011). Most nonessential metals (e.g., $\mathrm{Cd}, \mathrm{Hg})$ show a high affinity for proteins (Nordberg \& Nordberg, 2009). These chemicals may alter the synthesis and metabolism of proteins, because a wide range of harmful free radicals are formed when metals bind to proteins (Flora et al., 2008), thus causing pathophysiological effects in the organism and even suppression of the immune system
(Géret et al., 2002; Sharma et al., 2009). The current evidence has demonstrated that lesser-known hightechnology metals (e.g., Ta, rare earth elements) are contaminants of emerging concern (Gwenzi et al., 2018). Despite that, there is a lack of studies on those metals such as Ta, which are elements that are rapidly increasing because they possess vital properties for the development of emerging technologies in the field of electronics, biomedicine and advanced engineered systems (Karn, 2011).

The exposure of marine organisms (such as snails, mussels, gastropods, crustaceans and fish) to toxic metals can affect some physiological functions such as protein turnover; thus, those animals can be used as alert signs of the presence of these contaminants in the environment (Dallinger et al., 2000; Ivanina \& Sokolova, 2015). For that reason, it is crucial to develop tools to predict and detect these effects as soon as possi- 
ble, particularly in remote marine ecosystems. Antarctica and Patagonia have marine ecosystems that have not been profoundly affected by human presence, and can still be considered as pristine environments, although both can be exposed to the impact of global anthropogenic activities (Commendatore \& Esteves, 2007; Bargagli, 2008). Some marine animals have developed physiological adaptations such as icebinding (antifreeze) proteins that allow them to survive at low temperatures (Beers \& Jayasundara, 2015; Duman, 2015). A recent study showed that Ta bioaccumulates and biomagnifies throughout cold marine food chains (Espejo et al., 2018), but it is not known if this metal is bound to proteins or lipids. Some chemicals (e.g., persistent organic pollutants) tend to accumulate in lipid-rich tissues of organisms (Loganathan \& Kannan, 1994). We hypothesize that there is a positive relationship between Ta and protein contents across marine food webs conformed by macroinvertebrates and fishes in cold and pristine environments. Considering that Ta will be increasingly demanded, it is indispensable to study its possible implications in the environment and biota health. To date no studies have been conducted to show whether there is any relationship between Ta and protein contents in fauna of marine environments. The present study was conducted to investigate if there is any relationship between the contents of total protein and Ta from different marine coastal food webs. This work is a complement of our previous study (Espejo et al., 2018), in which we reported the Ta concentrations in the same organisms and locations studied here.

Samples of macroinvertebrates and fishes were collected during the austral summer of 2015 from different coastal marine ecosystems: a) Pan de Azúcar Bay $\left(26^{\circ} 09^{\prime} \mathrm{S}, 70^{\circ} 40^{\prime} \mathrm{W}\right.$ ) of northern Chile (a site which has been heavily contaminated in the past by

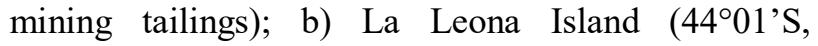
$\left.73^{\circ} 07^{\prime} \mathrm{W}\right)$ and Marchant River Mouth $\left(44^{\circ} 05^{\prime} \mathrm{S}\right.$, $73^{\circ} 05^{\prime} \mathrm{W}$ ) of Chilean Patagonia (despite their proximity, Marchant River Mouth and La Leona Island have different aquatic environments; while the sea surrounds the La Leona Island, Marchant River Mouth is located at the mouth of a freshwater river, which drags and discharges sediments with high organic matter content into the sea; both sites are far from human activities and with aquatic systems still considered pristine in Chilean territory); c) Fildes Bay $\left(62^{\circ} 12^{\prime} \mathrm{S}, 58^{\circ} 58^{\prime} \mathrm{W}\right)$ of South Shetland Islands, Antarctic Peninsula area (is a site belonging to the specially protected areas of Antarctica, as it has scientific and natural values). The samples of aquatic invertebrates were obtained using a Van Veen grab sampler or by scuba diving. Soft tissues of mollusks were extracted, whereas the whole body was retained for other macroinvertebrates. Fishes were captured using a harpoon and nets, anesthetized with 5\% benzocaine $\left(\mathrm{BZ}-20^{\circledR}\right.$, Veterquimica), euthanized through spinal severance, and then sampled for muscle tissue. All samples collected were washed with saline water and stored at $-20^{\circ} \mathrm{C}$ until their analysis in the laboratory. Later, samples were freeze-dried until dry masses were constant and then were homogenized into a fine powder using a glass mortar and pestle precleaned with $2 \%$ Conrad solution (Merck) for $24 \mathrm{~h}$, washed with deionized water and $\mathrm{HCl} 1 \mathrm{M}$ and rinsed with distilled water.

For protein analysis, a standard assay with Bradford reagent was used, which is based on the binding of Coomassie brilliant blue G-250 (SD Fine-Chem Limited) dye to basic amino acid residues at acidic $\mathrm{pH}$ (Noble \& Bailey, 2009). A Gen5's calibration protocol was used, with $\mathrm{R}^{2}$ values $>95 \%$. Calibration curves were obtained using bovine serum albumin (BSA) as a standard, prepared in Eppendorf tubes with concentrations ranging from 0.25 up to $1 \mathrm{mg} \mathrm{mL}^{-1}$ and then measured at $595 \mathrm{~nm}$. Simultaneously, approximately 5 $\mathrm{mg}$ of each lyophilized sample were placed in Eppendorf tubes. Then $1 \mathrm{~mL}$ of distilled water was added to each tube and mixed with plate shaker (Wise Cube, WIS-20) for $60 \mathrm{~s}$. Then, $10 \mu \mathrm{L}$ of this solution were extracted and placed in each well of 96-well polystyrene microplates. Finally, $250 \mu \mathrm{L}$ of Bradford reagent was added to each tube and mixed well. Protein solutions were assayed in triplicate. The absorbance values of all the samples and controls were measured at $595 \mathrm{~nm}$ after $5 \mathrm{~min}$ incubation at room temperature (BioTek Instruments, Inc., Winooski, VT, USA). In all cases, the coefficient of variation within triplicates was less than $20 \%$. For tantalum analysis, subsamples $(0.2$ g) were placed into $50 \mathrm{~mL}$ Teflon beaker with $5 \mathrm{~mL}$ of ultrapure nitric acid and heated (at $110^{\circ} \mathrm{C}$ ) until almost dry (about $3 \mathrm{~h}$ ). Then $5 \mathrm{~mL}$ of ultrapure nitric acid and $1 \mathrm{~mL}$ of hydrogen peroxide were added, and the mixture was heated again to near dryness (about $3 \mathrm{~h}$ ). The residue was dissolved in $5 \mathrm{~mL}$ of $1 \%$ ultrapure nitric acid, filtered with glass fiber filter ${ }^{\circledR}(<0.45 \mu \mathrm{m})$, and then transferred to a centrifuge tube. The last point was repeated four times to a final volume of $25 \mathrm{~mL}$. Total Ta was determined by mass spectrometry coupled with a plasma inductor (ICP-MS, NexION-350D, Perkin Elmer) at the Environmental Health Science Laboratory, Toyo University, Japan.

The relationship between $\mathrm{Ta}$ and protein content was analyzed by regressions of $\log _{10}$ Ta versus protein content in macroinvertebrates and fish at each location. We used analysis of covariance (ANCOVA) to determine whether the relationship between Ta level 
Table 1. Content of total protein $\left(\mathrm{g} \mathrm{g}^{-1}\right.$, dry weight), protein $(\%)$ and $\mathrm{Ta}\left(\mathrm{ng} \mathrm{g}^{-1}\right.$, dry weight $) \pm$ standard deviation in marine species from Pan de Azúcar Bay (northern Chile). ${ }^{1}$ Soft tissue (whole-body). ${ }^{2}$ Muscle. ${ }^{3}$ Minimum-maximum values. ${ }^{4}$ Reported by Espejo et al. (2018).

\begin{tabular}{|c|c|c|c|c|}
\hline Species & $\mathrm{n}$ & Total protein & $\%$ Protein $^{3}$ & $\mathrm{Ta}^{4}$ \\
\hline \multicolumn{5}{|l|}{ Macroinvertebrate $^{1}$} \\
\hline Cancer edwardsii & 5 & $0.149 \pm 0.062$ & $(8.1-22.8)$ & $0.47 \pm 0.16$ \\
\hline Fissurella spp. & 4 & $0.326 \pm 0.068$ & $(27.3-42.6)$ & $0.31 \pm 0.04$ \\
\hline Concholepas concholepas & 5 & $0.34 \pm 0.086$ & $(25.9-47.6)$ & $0.26 \pm 0.02$ \\
\hline Loxechinus albus & 5 & $0.252 \pm 0.089$ & $(11-34.1)$ & $0.51 \pm 0.09$ \\
\hline Aulacomya ater & 4 & $0.20 \pm 0.203$ & $(3.1-45.1)$ & $0.37 \pm 0.32$ \\
\hline Tegula atra & 5 & $0.256 \pm 0.038$ & $(19.5-28.6)$ & $0.34 \pm 0.17$ \\
\hline Crucibulum scutellatum & 5 & $0.093 \pm 0.031$ & $(6.1-13.1)$ & $0.17 \pm 0.07$ \\
\hline Forcipulatida spp. & 5 & $0.276 \pm 0.073$ & $(20.1-37.6)$ & $0.83 \pm 1.09$ \\
\hline \multicolumn{5}{|l|}{ Fish $^{2}$} \\
\hline Hemilutjanus macrophthalmos & 4 & $0.09 \pm 0.041$ & $(3.9-13.7)$ & $2.68 \pm 0.28$ \\
\hline Cheilodactylus gayi & 5 & $0.085 \pm 0.035$ & $(3.3-12.2)$ & $2.22 \pm 0.60$ \\
\hline Pinguipes chilensis & 2 & $0.067 \pm 0.012$ & $(5.8-7.5)$ & $2.09 \pm 0.39$ \\
\hline Trachurus symmetricus murphyi & 1 & 0.081 & 0.081 & 2.86 \\
\hline
\end{tabular}

Table 2. Content of total protein $\left(\mathrm{g} \mathrm{g}^{-1}\right.$, dry weight), protein $(\%)$ and $\mathrm{Ta}\left(\mathrm{ng} \mathrm{g}^{-1}\right.$, dry weight $) \pm$ standard deviation in marine species from La Leona Island and Marchant River mouth, Chilean Patagonia. ${ }^{1}$ Soft tissue (whole-body). ${ }^{2}$ Muscle. ${ }^{3}$ Minimum-maximum values. ${ }^{4}$ Reported by Espejo et al. (2018).

\begin{tabular}{|c|c|c|c|c|}
\hline Species & $\mathrm{n}$ & Total protein & $\%$ Protein $^{3}$ & $\mathrm{Ta}^{4}$ \\
\hline \multicolumn{5}{|l|}{$\begin{array}{l}\text { i) La Leona Island } \\
\text { a) Macroinvertebrate }\end{array}$} \\
\hline Concholepas concholepas & 3 & $0.30 \pm 0.051$ & $(25.4-35.4)$ & $0.38 \pm 0.17$ \\
\hline Cosmasterias lurida & 5 & $0.19 \pm 0.09$ & $(10.3-29.7)$ & $0.34 \pm 0.22$ \\
\hline Trophon geversianus & 5 & $0.174 \pm 0.053$ & $(9.9-23.4)$ & $0.29 \pm 0.12$ \\
\hline $\begin{array}{l}\text { Aulacomya ater } \\
\text { b)Fish }\end{array}$ & 5 & $0.08 \pm 0.054$ & $(3.7-15.7)$ & $0.23 \pm 0.11$ \\
\hline Genypterus chilensis & 1 & 0.161 & 16.1 & 1.83 \\
\hline Sebastes capensis & 5 & $0.312 \pm 0.052$ & $(26.3-39.4)$ & $1.84 \pm 0.28$ \\
\hline Pinguipes chilensis & 3 & $0.194 \pm 0.085$ & $(14.4-29.2)$ & $0.61 \pm 0.07$ \\
\hline \multicolumn{5}{|l|}{$\begin{array}{l}\text { ii) Marchant River Mouth } \\
\text { a) Macroinvertebrate }\end{array}$} \\
\hline Cancer coronatus & 7 & $0.277 \pm 0.075$ & $(19.2-37.9)$ & $1.51 \pm 1.05$ \\
\hline Fissurella spp. & 5 & $0.144 \pm 0.088$ & $(8.0-29.7)$ & $1.40 \pm 0.55$ \\
\hline Aulacomya ater & 4 & $0.089 \pm 0.052$ & $(2.3-13.9)$ & $1.05 \pm 1.81$ \\
\hline $\begin{array}{l}\text { Hemigrapsus crenulatus } \\
\text { b)Fish }\end{array}$ & 5 & $0.055 \pm 0.030$ & $(2.0-9.8)$ & $1.25 \pm 0.55$ \\
\hline Eleginops maclovinus & 5 & $0.232 \pm 0.050$ & $(17.5-30.8)$ & $2.48 \pm 0.27$ \\
\hline Salmo trutta & 1 & 0.103 & 10.3 & 2.03 \\
\hline Salmo salar & 2 & $0.139 \pm 0.017$ & $(12.6-15.1)$ & $2.20 \pm 0.12$ \\
\hline Genypterus chilensis & 2 & $0.210 \pm 0.032$ & $(18.8-23.3)$ & $2.08 \pm 0.06$ \\
\hline Graus nigra & 2 & $0.215 \pm 0.044$ & $(18.4-24.6)$ & $2.36 \pm 0.12$ \\
\hline
\end{tabular}

and protein content was significantly different among locations, which was achieved by comparison of the slopes obtained from the linear regressions. The differences among data were considered statistically significant when $P<0.05$. Statistical analyses were conducted using SPSS version 15.0 software (IBM Corp., Chicago, IL, USA).
The results showed that at Pan de Azúcar Bay (Table 1), the highest levels of proteins were found in Concholepas concholepas (a carnivorous gastropod, which feeds on peaks, limpets and mussels), while the highest Ta levels were found in Trachurus symmetricus murphyi (jack mackerel, a pelagic fish typical of the coast of northern Chile), which feeds on euphausiids 
Table 3. Content of total protein $\left(\mathrm{g} \mathrm{g}^{-1}\right.$, dry weight), protein $(\%)$ and $\mathrm{Ta}\left(\mathrm{ng} \mathrm{g}^{-1}\right.$, dry weight $) \pm$ standard deviation in marine species from Fildes Bay (South Shetland Islands, Antarctic Peninsula area). ${ }^{1}$ Soft tissue (whole-body). ${ }^{2}$ Muscle. ${ }^{3}$ Minimummaximum values. ${ }^{4}$ Reported by Espejo et al. (2018).

\begin{tabular}{lcccc}
\hline Species & $\mathrm{n}$ & Total protein & \% Protein & \\
\hline a) Macroinvertebrate & $\mathrm{Ta}^{4}$ \\
Nacella concinna & 4 & $0.061 \pm 0.026$ & $(3.9-9.6)$ & $1.22 \pm 2.17$ \\
Diplasterias brucei & 1 & 0.246 & 24.6 & 5.09 \\
Odontaster validus & 1 & 0.076 & 7.6 & 7.8 \\
Cnemidocarpa verrucosa & 1 & 0.057 & 5.7 & 3.48 \\
Actinia sp. & 5 & $0.124 \pm 0.071$ & $(5.1-22.2)$ & $2.35 \pm 1.03$ \\
Parborlasia corrugatus & 1 & 0.188 & 18.8 & $0.97 \pm 0.10$ \\
Abatus agassizii & 1 & 0.054 & 5.4 & $0.43 \pm 0.25$ \\
Sterechinus neumayeri & 5 & $0.063 \pm 0.020$ & $(4.6-9.8)$ & $0.43 \pm 0.44$ \\
Glyptonotus antarcticus & 3 & $0.041 \pm 0.029$ & $(1.1-6.9)$ & $1.33 \pm 0.40$ \\
b)Fish & & & \\
Trematomus scotti & 6 & $0.281 \pm 0.070$ & $(18.6-34.9)$ & $8.00 \pm 3.31$ \\
Pagothenia borchgrevinki & 1 & 0.393 & 39.3 & 13.7 \\
Notothenia coriiceps & 6 & $0.207 \pm 0.028$ & $(18.3-25.4)$ & $5.78 \pm 7.86$ \\
Notothenia rossii & 4 & $0.220 \pm 0.025$ & $(18.7-24.8)$ & $3.07 \pm 0.28$ \\
Pagothenia hansoni & 2 & $0.159 \pm 0.033$ & $(13.5-18.2)$ & $2.23 \pm 0.06$ \\
Notothenia kempi & 5 & $0.192 \pm 0.049$ & $(12.6-26.1)$ & $14.04 \pm 20.38$ \\
Trematomus newnesi & 1 & 0.223 & 22.3 & $2.8 \pm 0.68$ \\
\hline
\end{tabular}

Table 4. Regressions of $\log _{10}$ Ta $v s$. protein content for invertebrates and fishes collected from coastal locations in northern Chile, Chilean Patagonia, and Antarctic Peninsula area. Different letters indicate significant differences among slopes between different locations $(P<0.05)$.

\begin{tabular}{lccccl}
\hline Location & $\mathrm{n}$ & Slope & Intercept & $\mathrm{R}^{2}$ & $P$-value \\
\hline Pan de Azúcar Bay & 54 & $-0.017 \pm 0.005$ & $0.064 \pm 0.106$ & -0.193 & 0.0004 \\
La Leona Island $^{\mathrm{b}}$ & 27 & $0.020 \pm 0.007$ & $-0.743 \pm 0.146$ & 0.27 & 0.003 \\
Marchant River Mouth $^{\mathrm{b}}$ & 33 & $0.012 \pm 0.006$ & $-0.104 \pm 0.118$ & 0.12 & 0.024 \\
Fildes Bay $^{\mathrm{c}}$ & 47 & $0.041 \pm 0.007$ & $-0.314 \pm 0.135$ & 0.415 & $<0.0001$ \\
\hline
\end{tabular}

and mesopelagic fish (Medina \& Arancibia, 1992). At La Leona Island (Table 2), the highest levels of protein and $\mathrm{Ta}$ were found in Sebastes capensis (false jacopever, a pelagic fish typical of southern South America coast and western coast of South Africa, which feeds on small benthic invertebrates). At Marchant River mouth (Table 2), the highest levels of protein in macroinvertebrates were found in Cancer coronatus (crustacean, commonly called queen crab, which feeds on small mollusks and crustaceans of limited mobility), while the highest Ta levels were found in Eleginops maclovinus (a benthopelagic species which preferably consumes amphipods, polychaetes and crustaceans). At Fildes Bay (Table 3), the highest protein content was found in Pagothenia borchgrevinki (a cryopelagic species that usually feeds on copepods and krill), and the highest Ta levels were found in Notothenia kempi (striped-eyed rockcod, a demerso-pelagic fish widely distributed near the South
Shetland Islands, which feeds on sedentary polychaetes, amphipods and mollusks).

The regression analysis (Table 4) revealed that the slopes for the relationship between $\mathrm{Ta}$ and proteins in macroinvertebrates and fishes were statistically different between Antarctica (Fildes Bay) and the other sites $(P<0.037)$. In contrast, there were no differences between the sites of Patagonia (La Leona Island and Marchant River mouth, $P=0.389$ ). The slope for Fildes Bay was significantly higher than for all other sites, which could be explained as Antarctic marine food webs are simpler and mainly based on benthic and pelagic populations (Ballerini et al., 2014). The positive relationship between $\mathrm{Ta}$ and proteins we found here in marine species from Patagonia and Antarctica suggests that probably this metal binds to proteins, which would be consistent with evidence indicating that trace metals tend to bind to proteins (Hernández et al., 2006). Physiological characteristics, habitat, life 
cycle and environmental conditions can influence the chemical composition of biota (Diniz et al., 2012), which may explain why there was a negative relationship between these two variables at Pan de Azúcar Bay; heavy metals have impacted this northern location of Chile as a result of mining activities during the $20^{\text {th }}$ century (Celis et al., 2014), and many pollutants were probably re-suspended from sediments into the water column by floods that occurred in 2015 . Some studies suggest that there may be a reduction in total protein levels in some organisms from heavily chemical-contaminated environments (Sharma et al., 2009; Joseph \& Raj, 2010), and under such conditions possibly another contaminant might be competing with Ta by binding to proteins (Beyersmann \& Hartwig, 2008).

Our results indicate that Ta may interfere to some degree with proteins and thus affecting the immunological system of the species studied here. There is evidence that trace elements interfere with the physiological activity of proteins, thus reducing the immune capacity of the affected organism (Tamás et $a l ., 2014)$. Metals interfere with the biological activity of proteins by binding to free thiols or other functional groups, displacing essential metal ions of metalloproteins, or catalyzing the oxidation of the amino acid side chains (Sharma et al., 2009; Lemire et al., 2013). The functions of metalloproteins in cells are highly varied, acting as enzymes, transport and storage proteins, and in signal transduction (Waldron \& Robinson, 2009). By interfering with proteins, heavy metals could profoundly affect protein metabolism and cell viability (Tamás et al., 2014). Some researchers have found that the oxidative deterioration of biological macromolecules is mainly due to the binding of heavy metals to DNA and proteins at the nuclear level (Flora et al., 2008). The exposure to toxic metals of marine organisms can cause some degree of genotoxicity in them and, in this sense, metalloproteins have the potential to be used as biomarkers of early warning against the presence of trace elements (Petrovic et al., 2001; Cherian et al., 2003). A recent study found that Ta biomagnified along the same marine food webs studied here (Espejo et al., 2018). Although our results did not prove that Ta binds with proteins, they are indicating that proteins are probably the pathway by which Ta bioaccumulates and biomagnifies in macroinvertebrates and fishes of specific environments such as pristine coastal marine ecosystems.

Nevertheless, the protein values found in this study may also be influenced by factors intrinsic to the species studied (e.g., size, weight, sex, state of sexual maturity). Our data suggest that site-specific factors may be relevant in determining Ta environmental fate.
More studies are needed to elucidate any possible effects caused by Ta on marine fauna.

\section{ACKNOWLEDGMENTS}

This work was supported by the Instituto Antártico Chileno (INACH) through Project RG01-18 (J. Celis), by the Vicerrectoría de Investigación y Desarrollo of the Universidad de Concepción through Postdoc Project 219.153.026-P (W. Espejo), and by the Fondo Nacional de Ciencia y Tecnología (FONDECYT) through Project 1161504 (G. Chiang).

\section{REFERENCES}

Ballerini, T., Hofmann, E.E., Ainley, D.G., Daly, K., Marrari, M., Ribic, C.A., Smith, W.O. \& Steele, J.H. 2014. Productivity and linkages of the food web of the southern region of the western Antarctic Peninsula continental shelf. Progress in Oceanography, 122: 1029.

Bargagli, R. 2008. Environmental contamination in Antarctic ecosystems. Science of the Total Environment, 400: 212-226.

Beers, J.M. \& Jayasundara, N. 2015. Antarctic notothenioid fish: what are the future consequences of 'losses' and 'gains' acquired during long-term evolution at cold and stable temperatures? Journal of Experimental Biology, 218: 1834-1845.

Beyersmann, D. \& Hartwig, A. 2008. Carcinogenic metal compounds: recent insight into molecular and cellular mechanisms. Archives of Toxicology, 82: 493-512.

Celis, J.E., Espejo, W., González-Acuña, D., Jara, S. \& Barra, R. 2014. Assessment of trace metals and porphyrins in excreta of Humboldt penguins (Spheniscus humboldti) in different locations of the northern coast of Chile. Environmental Monitoring and Assessment, 186: 1815-1824.

Cherian, M.G., Jayasurya, A. \& Bay, B.H. 2003. Metallothioneins in human tumors and potential roles in carcinogenesis. Mutation Research, 533: 201-209.

Commendatore, M.G. \& Esteves, J.L. 2007. An assessment of oil pollution in the coastal zone of Patagonia, Argentina. Environmental Management, 40: 814-821.

Dallinger, R., Berger, B., Gruber, C., Hunziker, P. \& Sturzenbaum, S. 2000. Metallothioneins in terrestrial invertebrates: structural aspects, biological significance and implications for their use as biomarkers. Cellular and Molecular Biology, 46: 331-346.

Diniz, G.S., Barbarino, E. \& Lourenço, S.O. 2012. On the chemical profile of marine organisms from coastal subtropical environments: gross composition and nitrogen-to-protein conversion factors. In: Marcelli, M. (Ed.). Oceanography. InTech, Rijeka, pp. 297-320. 
Duman, J.G. 2015. Animal ice-binding (antifreeze) proteins and glycolipids: an overview with emphasis on physiological function. Journal of Experimental Biology, 218: 1846-1855.

Espejo, W., Kitamura, D., Kidd, K., Celis, J., Kashiwada, S., Galbán-Malagón, C., Barra, R. \& Chiang, G. 2018. Biomagnification of tantalum through diverse aquatic food webs. Environmental Science and Technology Letters, 5: 196-201.

Flora, S.J.S., Mittal, M. \& Mehta, A. 2008. Heavy metalinduced oxidative stress and its possible reversal by chelation therapy. Indian Journal of Medical Research, 128: 501-523.

Géret, F., Jouan, A., Turpín, V., Bebianno, M.J. \& Cosson, R.P. 2002. Influence of metal exposure on metallothionein synthesis and lipid peroxidation in two bivalve mollusks: the oyster (Crassostrea gigas) and the mussel (Mytilus edulis). Aquatic Living Resources, 15: 61-66.

Gwenzi, W., Mangori, L., Danha, C., Chaukura, N., Dunjana, N. \& Sanganyado, E. 2018. Sources, behavior, and environmental and human health risks of high technology rare earth elements as emerging contaminants. Science of the Total Environment, 636: 299-313.

Harms, H., Schlosser, D. \& Wick, L.Y. 2011. Untapped potential: exploiting fungi in bioremediation of hazardous chemicals. Nature Reviews Microbiology, 9: 177-192.

Hernández, A.J., Garbisu, C., Becerril, J.M., Barrutia, O., García, P.J.I., Zhao, F.J. \& Mcgrath, S.P.P. 2006. Synthesis of low molecular weight thiols in response to Cd exposure in Thlaspi caerulescens. Plant Cell and Environment, 29: 1422-1429.

Ivanina, A.V. \& Sokolova, I.M. 2015. Interactive effects of metal pollution and ocean acidification on physiology of marine organisms. Current Zoology, 61: 653-668.

Joseph, B. \& Raj, J. 2010. Effect of curacron toxicity on the total serum protein content of Cyprinus carpio. Toxicological \& Environmental Chemistry, 92: 18891893.

Received: 30 July 2019; Accepted: 20 November 2019
Karn, B. 2011. Inside the radar, select elements in nanomaterials and sustainable nanotechnology. Journal of Environmental Monitoring, 13: 1184-1189.

Lemire, J.A., Harrison, J.J. \& Turner, R.J. 2013. Antimicrobial activity of metals: mechanisms, molecular targets, and applications. Nature Reviews Microbiology, 11: 371-384.

Loganathan, B.G. \& Kannan, K. 1994. Global organochlorine contamination trends: an overview. Ambio, 23: 187-191.

Medina, M. \& Arancibia, H. 2002. Dinámica trófica del jurel (Trachurus symmetricus murphyi) en el norte de Chile. Investigaciones Marinas, Valparaíso, 30: 45-55.

Muñoz, J. \& Becker, P. 1999. The kelp gull as bioindicator of environmental chemicals in the Magellan region. A comparison with other coastal sites in Chile. Scientia Marina, 63: 495-502.

Noble, J.E. \& Bailey, J.A. 2009. Quantitation of protein. Methods in Enzymology, 463: 73-95.

Nordberg, M. \& Nordberg, F.G. 2009. Metallothioneins: historical development and overview. Metal Ions in Life Sciences, 5: 1-29.

Petrovic, S., Ozrectic, B., Krajnovic-Ozretic, M. \& Bobinac, D. 2001. Lysosomal membrane stability and metallothioneins in digestive gland of mussels as biomarkers in a field study. Marine Pollution Bulletin, 42: 1373-1378.

Sharma, G., Malla, F.A. \& Singh, S. 2009. An assay on the effect of indofil toxicity on the total serum protein content of Channa punctatus (Bloch). Biology and Medicine, 1: 25-27.

Tamás, M.J., Sharma, S.K., Ibstedt, S., Jacobson, T. \& Christen, P. 2014. Heavy metals and metalloids as a cause for protein misfolding and aggregation. Biomolecules, 4: 252-267.

Waldron, K.J. \& Robinson, N.J. 2009. How do bacterial cells ensure that metalloproteins get the correct metal? Nature Reviews Microbiology, 7: 25-35.

Zhou, Q., Zhang, J., Fu, J., Shi, J. \& Jiang, G. 2008. Biomonitoring: an appealing tool for assessment of metal pollution in the aquatic ecosystem. Analytica Chimica Acta, 606: 135-150. 